\title{
We should investigate social media's value properly
}

\author{
Damian T Roland consultant and honorary senior lecturer in paediatric emergency medicine
}

SAPPHIRE (Social Science Applied to Healthcare Improvement Research) Group, Health Sciences, Leicester University, Leicester LE1 7RH, UK

Social media have transformed traditional concepts of knowledge translation, ${ }^{12}$ and the rapid rise in conference "hashtags" creates its own knowledge gap. For some, this has resulted in a distorted perception of how Twitter works and how its use can be of benefit (or a hindrance). ${ }^{3}$

"Banning" Twitter is incongruous: you're not banning Twitter-you're banning its use to distribute what is perceived to be sensitive information. Conference organisers and presenters need to be clear about what information they are and aren't happy to share. ${ }^{4}$ This was the case before Twitter, so the issue relates to outdated copyright claims rather than the social medium itself.

We also need a sense check of the power of social media, Twitter in particular. Some conferences now have huge numbers of tweets and millions of potential impressions. Those new to Twitter may believe that anything and everything will be seen and "re-tweeted" by thousands. This is actually highly improbable given the large volume of competing information. For information to go "viral" it must be clear, picked up by key influencers, and relevant to a large number of healthcare professionals.
It's time for major publishers, conference organisers, and academic institutions to stop paying lip service to social media as an add-on and truly investigate its potential value and/or perils. Speakers and delegates will benefit and won't be confused by outdated policies and rules.

Competing interests: None declared.

Full response at: www.bmj.com/content/353/bmj.i3556/rr-0.

1 Groves T. Tweeting and rule breaking at conferences. BMJ 2016;353:i3556. doi:10.1136/ bmj.i3556 pmid:27352951.

2 Roland D, Trueger S, Thoma B, Chan T. FOAM helps to bridge the knowledge translation gap. Letter to the editor re: Pundit-based medicine. Emergency Physicians International 2016;18:34. www.epijournal.com/articles/246/foam-helps-to-bridge-the-knowledgetranslation-gap.

3 Roland D, May N, Body R, Carley S, Lyttle M. Will social media make or break medical conferences?Br J Hosp Med (Lond) 2015;76:318-9. doi:10.12968/hmed.2015.76.6. 318 pmid:26053900.

4 Roland D, May N, Body R, Carley S, Lyttle MD. Are you a SCEPTIC? SoCial mEdia Precision \& uTility In Conferences. Emerg Med J 2015;32:412-3. doi:10.1136/emermed2014-204216 pmid:25504658

Published by the BMJ Publishing Group Limited. For permission to use (where not already granted under a licence) please go to http://group.bmj.com/group/rights-licensing/ permissions 